ICES Journal of Marine Science

January 2006; 63(1) : 128-139

http://dx.doi.org/10.1016/j.icesjms.2005.06.010

(C) 2005 International Council for the Exploration of the Sea

Published by Elsevier Ltd.
Archimer, archive institutionnelle de l'Ifremer http://www.ifremer.fr/docelec/

\title{
Activity patterns, home-range size, and habitat utilization of Sarpa salpa (Teleostei: Sparidae) in the Mediterranean Sea
}

\author{
C. Jadot ${ }^{a^{*}}$, A. Donnay ${ }^{a}$, M.L. Acolas ${ }^{b}$, Y. Cornet $^{c}$ and M.L. Bégout Anras ${ }^{b}$ \\ aDepartment of Eco-ethology, University of Liege, Aquarium “M. Dubuisson”, Quai Van Beneden 22, 4020 Liège, \\ Belgium \\ ${ }^{\mathrm{b}}$ CREMA L'Houmeau, UMR 10 (CNRS/IFREMER), B.P. 5, 17137 L'Houmeau, France \\ 'Department of Cartography and Geography, University of Liege, Allée du 6 Août, 17, 4000 Liège, Belgium \\ *: Corresponding author : tel: +32 436650 18; fax: +32 436650 93. catherine.jadot@ulg.ac.be
}

\begin{abstract}
Acoustic telemetry was used to record diel movement and habitat utilization of the salema (Sarpa salpa) (Teleostei: Sparidae) during three consecutive summers from 2000 to 2002 in the Calvi and Achiarina bays of Corsica in the Mediterranean Sea. A total of 18 fish was equipped with acoustic transmitters inserted in the body cavity, 13 were tracked in the Bay of Calvi ( $275 \mathrm{~mm} \pm 26.9 \mathrm{LF}$ ), and 5 in Achiarina Bay ( $260 \mathrm{~mm} \pm 33.6 \mathrm{LF})$. Two different systems were used to track the fish. The one used in the Bay of Calvi was a manual receiver and a directional hydrophone. The second system, used in Achiarina Bay, was a radio-acoustic-positioning (RAP) system that continuously monitored the movements of the fish. Fish positions were put in a geographic information system (GIS) with information on the substratum and depth. Two patterns of behaviour could be identified in the three years. Either the fish had clearly defined daytime as opposed to night-time areas of residency, characterized by different depths and substrata or the fish persistently occupied the same sites during both day and night. In the Bay of Calvi, six fish were released $1 \mathrm{~km}$ from the capture site. All of them showed homing ability and returned to the site within $48 \mathrm{~h}$.
\end{abstract}

Keywords: GIS; habitat utilization; home range; homing; manual tracking; Sarpa salpa; telemetry; VRAP 


\section{Introduction}

The salema, Sarpa salpa (L.), is an eurytherm species widely distributed throughout the Mediterranean and the Eastern Atlantic coast (round South Africa to South of Mozambique including the Azores and Canary Islands) (Bouchot and Hureau, 1990). In the last fifteen years, this poorly studied species in the Mediterranean Sea has attracted research interest for (i) its role as macro-grazer of seagrass (Velimirov, 1984; Havelange et al., 1997; Jadot et al., 2000, 2002), (ii) its biology in order to develop a management strategy (Méndez Villamil et al. 2001, 2002) and (iii) its toxicity which can cause Ciguatera-like or Caulerpa poisoning when consumed (Spanier 1988, Spanier et al., 1989, Chevaldonne, 1990).

This species is a protandrous hermaphrodite (Lissa-Frau 1966, 1968, Sellami and Bruslé, 1975); males are predominant between 150 to $300 \mathrm{~mm}$ and females from 310 to $450 \mathrm{~mm}$. Common to many Sparidae sex conversion takes place over wide range of sizes (230-350 mm) (Méndez Villamil et al. 2002); and as no external dimorphism exists, sex determination based only on size remains difficult.

S. salpa is ecologically significant in the Posidonia oceanica seagrass meadows, endemic of the Mediterranean Sea. This species account for up to $75 \%$ of the total herbivorous consumption (Cebrian et al., 1996) and represent a significant part of the fish fauna (40-70\% in biomass) (Francour, 1997, 2000). Herbivores, and more specifically the salema, in such ecosystem are subsequently an essential link to higher levels of the food web as consumers of primary production. In the temperate meadows the herbivores are little represented comparatively to the tropical ones. Generally, authors assumed that they are a minor factor in the control of $P$. oceanica since grazing accounts only for a small percentage of leaf production (2 to 15\% of the leaf production: Velimirov, 1894; Cebrian et al., 1996; Havelange et al., 1997; Pergent et al., 1997; Cebrian and Duarte, 2001). Nevertheless this assumption is discussed and recent literature suggest that the role of the herbivores in the temperate zones is more important than generally thought (Verlaque, 1990; Cebrian et al., 1996, 1997; Ojeda \& Munoz, 1999; Ruitton et al., 2000).

With the recent progress of biotelemetry in marine environment, valuable information such as home range, habitat selection and activity of free swimming fishes is now accessible (Winter, 1996). The main objective of this study was to gain a better understanding of the ecological and ethological interactions between the salema and the Mediterranean P. oceanica meadow. Specific aims of this work were to determine space and substratum utilisation and the daily activity patterns of this species, using two methods of acoustic telemetry (manual tracking with a portable receiver and an automatic tracking with a radio linked acoustic positioning system).

\section{Materials and methods}

Study site

This research took place at two different sites of the Mediterranean Sea, on the Corsican coast. The first study was carried out near the marine research station STARESO (STAtion de REcherche océanographique et SOus-marine) in the Calvi bay $\left(42^{\circ} 35^{\prime} \mathrm{N}-8^{\circ} 43^{\prime} \mathrm{E}\right)$ (Fig. 1) between June 2000 and September 2002.

The second study took place on the Lavezzi Islands in the Achiarina bay, $\left(41^{\circ} 20^{\prime} \mathrm{N}-\right.$ $\left.9^{\circ} 15^{\prime} \mathrm{E}\right)$ (Fig. 1). The meteorological conditions were particularly hard during the tracking month (October 2002) with winds remarkably violent and dominant in the sector West (Fig. 1). 
Fig. 1. Map of Corsica showing the two study sites, the Calvi Bay and the Lavezzi Islands. The capture sites are indicated for each study site.

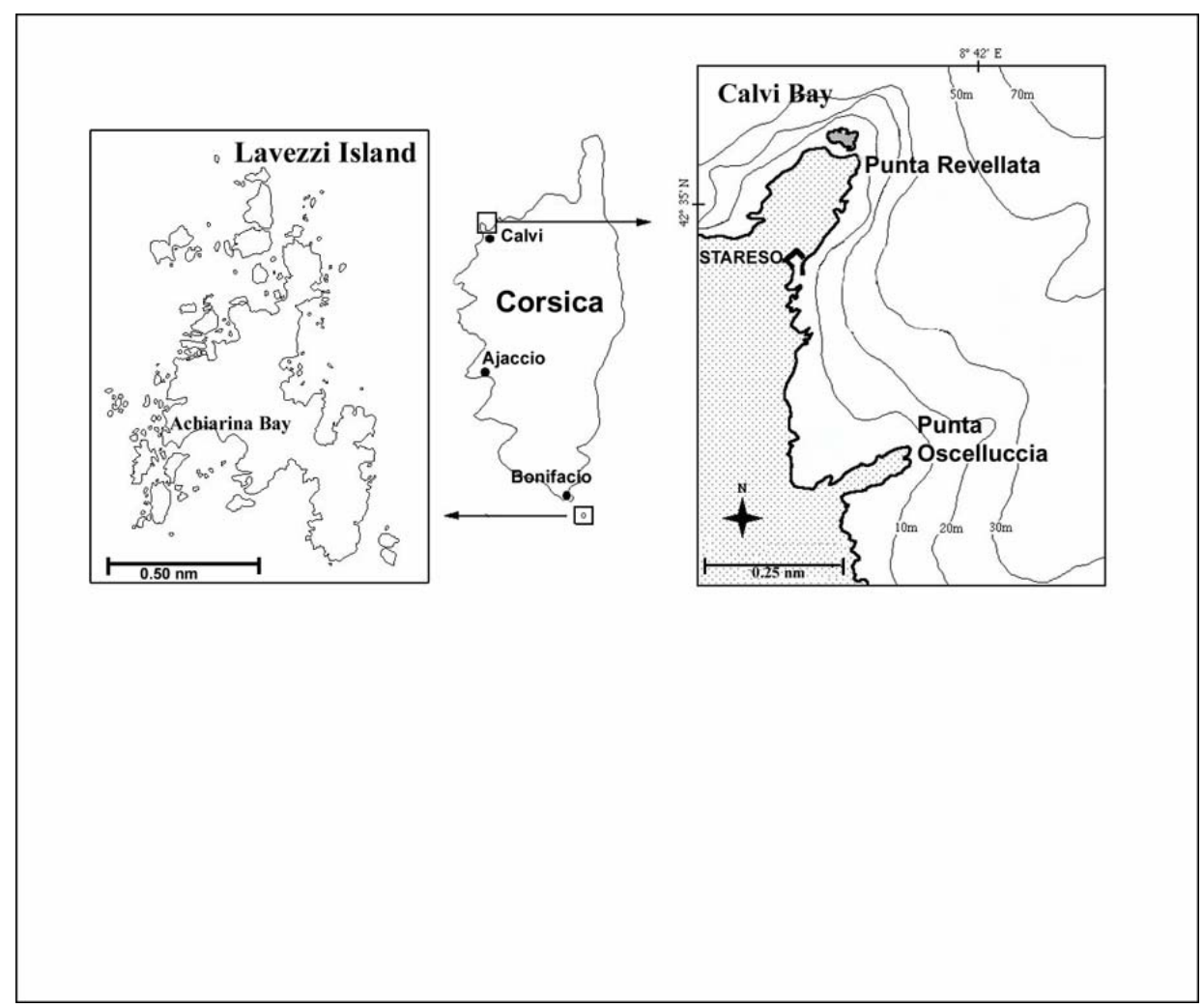

\section{Habitat mapping}

Calvi bay - Substratum and depth information of the study site were collected by Sargian (1997) via aerial photography and SCUBA diving observations. The coast near the station consists of granite rocks going down into the sea to a depth of $8 \mathrm{~m}$ (in front of the station) to 30 $\mathrm{m}$ (at the end of the Punta Revellatta) (figure 2A). The rocky substratum is made of granite blocks of variable size (scale decimetric to decametric) more or less piled up depending of the area. A rich macroalgal biocenosis (epilithic algal) dominated by Cystoseira spp cover those rocks. Over the rocky area, the Posidonia oceanica grows on a gently sloped bottom down to the $38 \mathrm{~m}$ isobath where the meadow is replaced by a sandy-gravel bottom. All data were input to Arcview GIS (Ersi ${ }^{\mathrm{TM}}$, Inc., Redlands, California) to form a depth-substrate theme. A fifth area was mathematically added to the substratum map. It's a buffer zone between the meadow and the sandy area of the shallow water. This zone was calculated as $10 \mathrm{~m}$ on both side of the limit between the two areas.

Achiarina bay - Substratum and depth information was collected by de Vaugelas et al. (1995). The coast around the island, comparable to the Calvi bay, is characterised by a dense $P$. oceanica meadows with sandy area patches (figure 2B).

Fig. 2A. Different substrata types in the Calvi Bay (Corsica - France). 2B. Different substrata types in the Achiarina Bay (Corsica - France).

Cf. eps file 
In the Calvi bay, more than 150 SCUBA dives were made to observe habitat characteristics and fish behaviour from June 2000 to October 2002, 10\% of the dives were made at night. In the Lavezzi Islands, due to the bad weather conditions, we were able to dive only 4 times during the tracking period and only once at night.

\section{Fish tagging}

Fish tracked in the Calvi bay were captured with gill nets while SCUBA diving near Stareso in shallow waters $(<15 \mathrm{~m}$ ) (figure 1 ). After capture, the fish were directly transferred in tanks, containing water from the capture site, in order to minimise perturbations. Fish from the Lavezzi Islands were captured following the same protocol but were placed in a cage prior to tagging (figure1).

The fish were anaesthetised using a $0.2 \mathrm{ml} \mathrm{I}^{-1}$ solution of 2-phenoxy-ethanol. When they were fully anaesthetised, showing no reaction to external stimuli, they were weighed to the nearest gram and measured to the nearest $\mathrm{mm}$ (fork length, FL) (Table 1). Then they were placed ventral side up into a V-shaped support adjusted to their morphology. The whole body but the ventral side stayed in the water, to avoid dehydration and to permit a continuous oxygenation of the gills. After cleaning in iso-Betadine, the transmitters (V8-1L $(38 \times 8 \mathrm{~mm} 2)$ and V8-2L (24 $\times 8 \mathrm{~mm} 2)$ ) were inserted into the peritoneal cavity and the wound closed using two sutures (Jadot, 2003). The transmitters did not exceed $2.6 \%$ of the body weight of the fish (Table 1). The procedure took less than $10 \mathrm{~min}$. Following full recovery in a fresh seawater tank, the fish were released in respective capture sites. 
Table 1. Characteristics of the Sarpa salpa tagged. TW and TBWR are 'transmitter weight in air' and 'transmitter to body weight ratio' in air. $L$ is the loss of the fish, $D$ the death of the fish and $T$ the end of the transmitter battery life, $E$ end of the tracking period. Fish 13 to 18 were tracked with the automatic system.

\begin{tabular}{|c|c|c|c|c|c|c|c|c|c|c|c|c|c|c|c|c|c|c|}
\hline 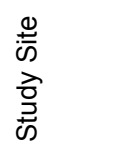 & 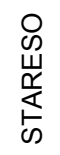 & 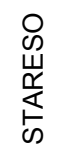 & 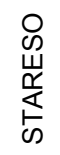 & 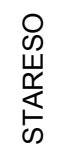 & 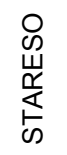 & $\begin{array}{l}0 \\
\stackrel{\infty}{W} \\
\frac{w}{\underline{\alpha}} \\
\frac{5}{5}\end{array}$ & $\begin{array}{l}0 \\
\stackrel{\infty}{W} \\
\stackrel{w}{\frac{w}{5}} \\
\infty\end{array}$ & 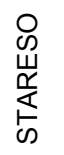 & 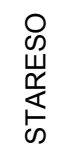 & 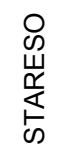 & 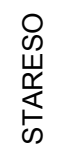 & 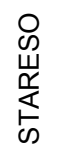 & 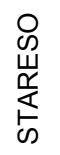 & $\begin{array}{l}\bar{N} \\
\stackrel{N}{N} \\
\stackrel{\Xi}{J}\end{array}$ & \multicolumn{2}{|c|}{ 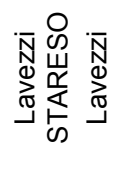 } & $\begin{array}{l}\bar{N} \\
\underset{N}{\mathbb{J}} \\
\stackrel{\mathbb{J}}{ }\end{array}$ & $\begin{array}{l}\bar{N} \\
\stackrel{N}{N} \\
\stackrel{N}{N}\end{array}$ \\
\hline \begin{tabular}{|l}
0 \\
0 \\
0 \\
0 \\
0 \\
0 \\
$\frac{\pi}{\pi}$ \\
0
\end{tabular} & 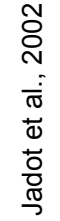 & 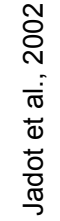 & 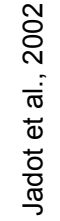 & 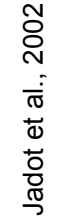 & 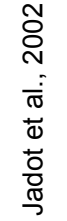 & 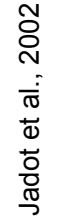 & 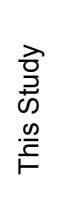 & 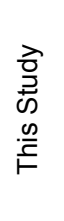 & $\begin{array}{l}\overrightarrow{0} \\
\stackrel{\vec{D}}{0} \\
.00 \\
\vec{F}\end{array}$ & 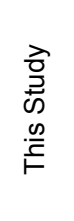 & 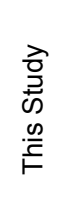 & 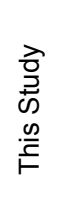 & 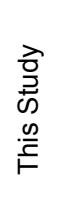 & 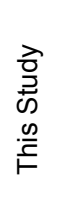 & 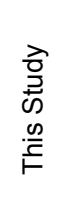 & 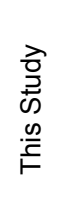 & $\begin{array}{l}\overrightarrow{0} \\
\stackrel{\vec{D}}{0} \\
.00 \\
\vec{F}\end{array}$ & 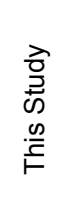 \\
\hline 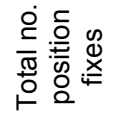 & $\stackrel{\llcorner}{\infty}$ & $\simeq$ & $\bar{\gamma}$ & $\stackrel{\infty}{\infty}$ & ஜ & $\stackrel{\infty}{+}$ & $\stackrel{\infty}{\sigma}$ & g & ${ }^{\infty}{ }^{\infty}$ & $\stackrel{\circ}{=}$ & ळి & $\stackrel{m}{\circ}$ & ৪ & $\mp$ & $\stackrel{6}{\llcorner}$ & م & & 0 \\
\hline 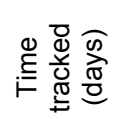 & $m$ & م & $\simeq$ & $\digamma$ & $\approx$ & $\stackrel{\infty}{\leftarrow}$ & $\infty$ & g & g & $\stackrel{\circ}{\circ}$ & $\stackrel{\varnothing}{\circ}$ & $\stackrel{\circ}{\circ}$ & $F$ & - & - & - & 0 & - \\
\hline 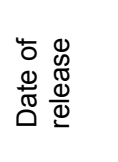 & $\begin{array}{l}8 \\
0 \\
0 \\
5 \\
0 \\
0\end{array}$ & $\begin{array}{l}8 \\
0 \\
0 \\
5 \\
5 \\
9 \\
m\end{array}$ & $\begin{array}{l}8 \\
0 \\
\Xi \\
5 \\
\bar{N}\end{array}$ & $\begin{array}{l}8 \\
8 \\
\frac{1}{5} \\
5 \\
0\end{array}$ & 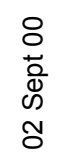 & 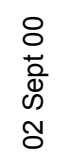 & $\begin{array}{l}5 \\
\overline{3} \\
\overline{3} \\
\mathfrak{N}\end{array}$ & 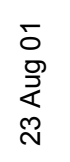 & $\begin{array}{l}\delta \\
\text { Oे } \\
\stackrel{z}{\$} \\
\text { N }\end{array}$ & 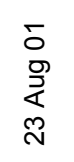 & $\begin{array}{l}\delta \\
\text { Oे } \\
\stackrel{8}{0} \\
\text { N }\end{array}$ & 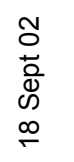 & 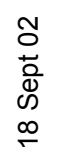 & 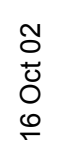 & \begin{tabular}{l}
\multirow{O}{N}{} \\
$\stackrel{0}{0}$ \\
0 \\
0
\end{tabular} & 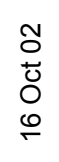 & $\begin{array}{l}\widetilde{O} \\
\overleftarrow{U} \\
0 \\
0\end{array}$ & $\begin{array}{l}\tilde{O} \\
\tilde{U} \\
0 \\
0 \\
0\end{array}$ \\
\hline 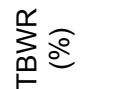 & $\stackrel{L}{0}$ & $\hat{o}$ & $\stackrel{9}{\circ}$ & $\stackrel{\nabla}{0}$ & 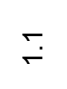 & $\hat{o}$ & $\stackrel{m}{\leftarrow}$ & $\stackrel{n}{\longrightarrow}$ & $\bar{i}$ & $\stackrel{\bullet}{\sim}$ & $\stackrel{\text { ?ִ }}{\longrightarrow}$ & $\stackrel{m}{\longrightarrow}$ & $\stackrel{f}{=}$ & $\stackrel{n}{\longrightarrow}$ & $\stackrel{\infty}{\leftarrow}$ & $\stackrel{\leftrightarrow}{i}$ & $\stackrel{\infty}{-}$ & $\stackrel{\leftrightarrow}{i}$ \\
\hline$\gtreqless \widehat{O}$ & $\hat{i}$ & $\stackrel{\leftrightarrow}{\infty}$ & $\stackrel{\infty}{\infty}$ & $\hat{i}$ & 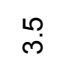 & $\stackrel{\infty}{\infty}$ & $\stackrel{m}{m}$ & $\stackrel{\gamma}{\dot{\gamma}}$ & $\hat{\sim}$ & $F$ & $\stackrel{\sim}{\dot{f}}$ & $\stackrel{\sim}{\dot{\sigma}}$ & 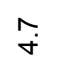 & $\stackrel{m}{m}$ & 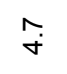 & $\stackrel{\gamma}{\dot{\gamma}}$ & $\stackrel{m}{m}$ & $\hat{\dot{\sigma}}$ \\
\hline 蓠 & ర్ల & প্ণ & $\stackrel{0}{\stackrel{0}{\infty}}$ & ల్ల & $\frac{m}{m}$ & 守 & $\stackrel{\&}{~}$ & \&్ల & 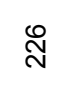 & $\stackrel{\mathscr{N}}{\underset{\sim}{*}}$ & 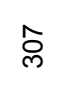 & ষ্ল & $\stackrel{?}{\stackrel{2}{N}}$ & సิ & 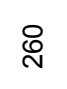 & $\stackrel{\infty}{\leftarrow}$ & $\stackrel{\infty}{\leftarrow}$ & 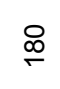 \\
\hline 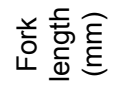 & $\stackrel{\mathbb{D}}{\sim}$ & $\stackrel{\infty}{\stackrel{\infty}{N}}$ & $\stackrel{\infty}{\sim}$ & $\hat{m}$ & $\stackrel{g}{\sim}$ & $\stackrel{\mathbb{D}}{\sim}$ & $\stackrel{\sim}{N}$ & 足 & $\stackrel{\mathscr{N}}{\mathrm{N}}$ & $\frac{\Omega}{m}$ & $\stackrel{8}{\circ}$ & $\stackrel{\infty}{\stackrel{\infty}{N}}$ & $\stackrel{\infty}{\sim}$ & $\stackrel{\sim}{N}$ & $\stackrel{N}{N}$ & $\stackrel{g}{N}$ & $\bar{i}$ & $\stackrel{N}{N}$ \\
\hline$\frac{5}{\frac{5}{4}} \frac{0}{8}$ & - & $\sim$ & $m$ & $\sigma$ & n & 0 & $\Lambda$ & $\infty$ & o & 으 & $F$ & $\stackrel{\simeq}{ }$ & $\stackrel{m}{\sim}$ & $\nabla$ & $\stackrel{20}{2}$ & $\stackrel{\circ}{\circ}$ & 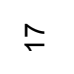 & $\stackrel{\infty}{\sim}$ \\
\hline
\end{tabular}




\section{Manual tracking}

Manual tracking was conducted from a boat equipped with a $\mathrm{VH} 10$ unidirectional hydrophone (VEMCO Ltd, Nova Scotia) and a VR60 receiver (VEMCO Ltd, Nova Scotia). The tracking equipment was fastened to a small skiff to allow tracking by a single operator and rapid changes of direction, and to reduce the hydrodynamic and mechanical noise (Holland et al., 1992).

Accuracy of the manual tracking method depends on several factors at sea. The depth of the transmitter and the presence or absence of a thermocline, which operates as an acoustic barrier, affects the accuracy of location fixing. Moreover, vegetation, rocks, waves (in severe weather condition) and others obstacles can reduce the power of the signal, and therefore may alter the accuracy of the location. Jadot et al. (2002) estimated, at the same study site, the accuracy of the fixes ranged from 10 to $50 \mathrm{~m}$.

After locating the fish on each survey day, bearings were taken on three landmarks and the fish position was noted in a logbook.

At the beginning of the study, to minimise the possibility of loosing the fish, positional fixes were taken every 30 minutes from dawn to dusk. As a movement pattern and habitat utilisation of S. salpa emerged, positional fixes were taken every two hours, excepted during the $24 \mathrm{~h}$ cycles were the positional were taken every 4 hours (table 2 ).

Table 2. Temporal stratification of the tracking in the Calvi bay by manual tracking.

\begin{tabular}{ll}
\hline Year & \multicolumn{1}{c}{ Positioning } \\
\hline 2000 & Every 30 minutes \\
2001 & Every 2 hours \\
2002 & Every 2 hours \\
& 24h cycles: every 4 hours \\
\hline
\end{tabular}

VRAP

A radio-linked acoustic positioning array (VRAP, VEMCO Ltd, Nova Scotia) was moored in October in the Achiarina bay. The system was composed of three buoys aligned in a triangular array. Each RAP buoy consists of an unidirectional hydrophone and receiver for detecting ultrasonic signals and a VHF modem and antenna for simultaneous communication to the base station. The base station, installed on shore, decodes the signals from each RAP buoy and plots in real-time, detailed position information from underwater transmitters on a computer monitor before saving the data on a hard disk. This system is more expensive than the manual tracking and requires more logistical support (e.g. boat big enough to place the buoys, divers to moor the buoys, home base for reception of the radio transmitted signals). However, the advantages of the VRAP system are twofold. Firstly, it remotely triangulates an accurate position of each fish. Several studies have tested the position accuracy of the VRAP system and they estimated an accuracy as good as 1 to $3 \mathrm{~m}$, with positions farther from the array less accurate (Bégout Anras et al., 1999; Klimley et al., 2001, Zamora and Moreno-Amich, 2002). Secondly, the system operates autonomously, and is thus able to record the positions of the fish over a longer period than the labour intensive, manpower demanding, manual tracking aboard a ship; and this over $24 \mathrm{~h}$ per day (Klimley et al., 2001).

The array was anchored on the western side of the Lavezzi Island to protect the sonobuoys from the violent currents and waves very frequent in this period of the year on the island. Location of the array was also adapted after the prior detection of the tagged fish by manual tracking system. The base station on the island communicated with each buoy individually, tuning automatically to listen to a prescribe frequency every 20 seconds. The data were subsequently converted to one minute intervals.

\section{Displacement experiment}

SCUBA diving observations of fish released immediately after tagging suggested that the fish returned to the point of capture. To investigate the ability of this species to return to a specific location we conducted a displacement experiment. Three S. salpa were released at locations 625 from the capture point and three at 850 m (namely Punta Revellata and Punta 
Oscelluccia, Figure 1). Seven were released at the capture site as: control group. The return of these displaced tagged fish to the point of capture was observed by the same tracking techniques used for the other fish, positional fixes were taken directly following release.

\section{Integrating telemetry data with GIS}

Each position, manually or automatically taken, was recorded with date, time and fish ID. The data files produced by the automated tracking system gave fish position data tables using an arbitrary coordinate system. Those coordinates were transformed to a geodetic coordinate (Lambert 2) and interpretated as a theme in the Arcview ${ }^{\circledR} \mathrm{GIS}$ environment (Ersi ${ }^{\mathrm{TM}}$, Inc., Redlands, California). Animal movement extension (Hooge et al., 1997) was used to analyse the movement data.

\section{Data treatments}

A series of descriptive statistics of the fish movement were calculated using Animal Movement Analyst Extension (AMAE) of Arcview ${ }^{\circledR}$ (Hooge et al., 1997) to represent basic behaviour. The overall track distance is the sum of distances between consecutive points $(\mathrm{m})$. The maximum speed is the maximum distance travelled per day (m/day). The Core area, correspond to the $50 \%$ Kernel home range $\left(\mathrm{m}^{2}\right)$. The dispersion of the data $\left(\mathrm{r}^{2}\right)$ is the mean squared distance (MSD) from the centre of activity $\left(\mathrm{m}^{2}\right)$. The eccentricity is the ration between the minor and the major axis length of range. This program also calculated a fixed kernel home range (KHR) utilisation distribution as a grid coverage using ad hoc calculation of a smoothing parameter $(\mathrm{H})$ by the least squares cross validation. The KHR is calculated for a probability of 95,75 and $50 \%$ to find the fish. The $95 \%$ contour is usually considered as the area the animal actually uses (the home range) and the $50 \%$ contour as the core area of activity (Hooge et al., 1997). As the KHR function does not recognize land vs. water substrate, the KHR was calculated for each fish using the AMAE extension, all land areas were clipped out using ArcView geoprocessing tools, and then the area of the KHR contours was recalculated with the land areas clipped out. This has not been made in Jadot et al. (2002) and explains the differences observed for the fish 1 to 6 . Paired $t$ tests were run to compare differences between the sizes of day and night home ranges of all subjects. All statistical analyses were performed with Stat View 5.0.1® (SAS Institute Inc., Cary, North Carolina). Those data could not have been calculated for the fish $14,15,16$ and 18 due to the reduced number of positional fixes obtained.

The dawn period was established as one hour before sunrise given by the French IMCCE (Institut de Mécanique Céleste et de Calcul d'Éphémérides, http://www.imcce.fr), and the dusk as one hour before the sunset. Those periods were adjusted to every fish in relation to the months of the tracking session (from June to October).

The activity patterns were measured by the mean distance moved between consecutive fixes taken at fixed intervals. We used a non parametric Friedman test to test the null hypothesis: Salemas utilize each habitat category in identical proportion. After the null hypothesis was rejected, an adjustment of the $\alpha$-level was realised by a Bonferroni correction to allow multiple comparisons. The different substratums were then tested against each other to detect preference or avoidance of individual habitat (Wilcoxon Signed Rank test). The Spearman correlation test was used to analyse the relation between the size of the fish and the core area of the home range (level of decision used $r=0.09, p>0.05$ ). The Kruskal-Wallis test was applied to compare the size of the home range of the different fish ( $d f=4, p>0.05$ ). The non-parametric paired t test was used to compare the size of the day and night home range of all the fish at 50,75 and $95 \%$ contour level $(\mathrm{df}=12, \mathrm{p}<0.01)$.

\section{Results}

\section{The Bay of Calvi}

A total of 13 Sarpa salpa were successfully tagged and tracked between 08 June 2000 and 18 September 2002. A total of 285 individual fish tracking days were collected and 721 dawn-, 2151 day-, 742 dusk- and 378 night-time position fixes were acquired. These data are summarised for each fish in Table 1 . The number of days tracked per fish was variable, ranging from 3 to 49 days, with a mean of 21.9 days. Likewise, the number of position fixes per fish was 
also highly variable, ranging from 85 to 594 with a mean of 307 positions. Low number of tracking days and position fixes for the fish 1 and 2 (respectively: 3 and 5 days of tracking; 85 and 121 position fixes) were due to the loss of fish 1 and death of the fish 2 . The fish 2 was found cut in two parts on the bay bottom. Natural predation could not be ruled out, but was considered as unlikely; therefore capture by leisure fisherman or cut by a boat propeller was considered the most likely cause of death.

\section{Activity patterns}

As shown by Jadot et al. (2002) for fish 1 to 6 , the same pattern of activities was found here for the 7 other fish studied. Sarpa salpa exhibited a distinct diurnal activity pattern, remaining inactive by night and then moving during daytime. Diurnal activities usually started within an hour after sunrise and ended within $30 \mathrm{~min}$ to $1 \mathrm{~h}$ before sunset. During the observational dives, the fish were observed actively grazing during the day and resting during the night. The twilight periods were transitional periods where intermediary behaviours of the fish were observed. $S$. salpa grazed less and were more mobile during dawn and dusk (mean distance moved respectively $1.9 \pm 0.6 \mathrm{~m} . \mathrm{s}^{-1}$ and $1.4 \pm 0.7 \mathrm{~m}^{-1} \mathrm{~s}^{-1}$ ) than during the day or the night (mean distance moved respectively $0.8 \pm 0.2 \mathrm{~m} \mathrm{~s}^{-1}$ and $0.7 \pm 0.3 \mathrm{~m} . \mathrm{s}^{-1}$ ) (Fig 3).

Fig. 3. Mean and maximum distance moved (m.s-1) (respectively bars and squares) between consecutive fixes during the $24 \mathrm{~h}$ cycle for the fish in the Calvi Bay.

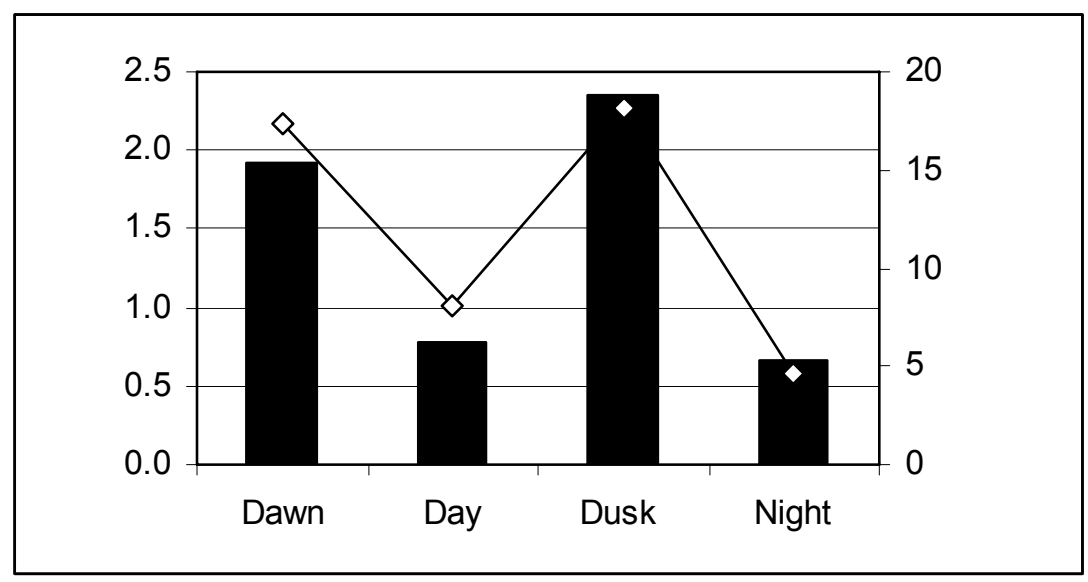

The fish stayed on a restricted area during the day, and then they moved to a resting area. The resting area was (1) either the same as the day area or (2) an area situated at maximum $1 \mathrm{~km}$ from the day site (figure 4). All the fish but fish 1 and 4 used those two types of area for the night home range. No correlation with weather condition, tides or external influences was found to explain the shift in the two zones of night areas. Moreover, fish tracked simultaneously were moving from a resting site to another one independently.

The overall track distance was highly variable from one fish to another one, ranking from 4 $752.5 \mathrm{~m}$ to $55260.8 \mathrm{~m}$. The maximum speed observed was ranking from 9.3 to $992 \mathrm{~m} /$ day, with the maximum observed for fish 8 (table3).

Of the 6 fish displaced from the point of capture, by 625 or $850 \mathrm{~m}, 100 \%$ returned to the point of capture within $2 \mathrm{~d}$. The control 7 fish released at the capture site remained there.

Direct qualitative observations in SCUBA have shown that the path used by the fish from one activity area to another was always the same, following the coast to join one or another site. 
Fig. 4. Night and day positional fixes for the fish 5 and 7 in the Calvi Bay on the different substratum. 1.is sand; 2 . is the limit zone between the sand and the meadow; 3 . is the meadow of Posidonia oceanica; 4 . is the epilithic algae; 5 . is the deep sand. The land is represented in black.
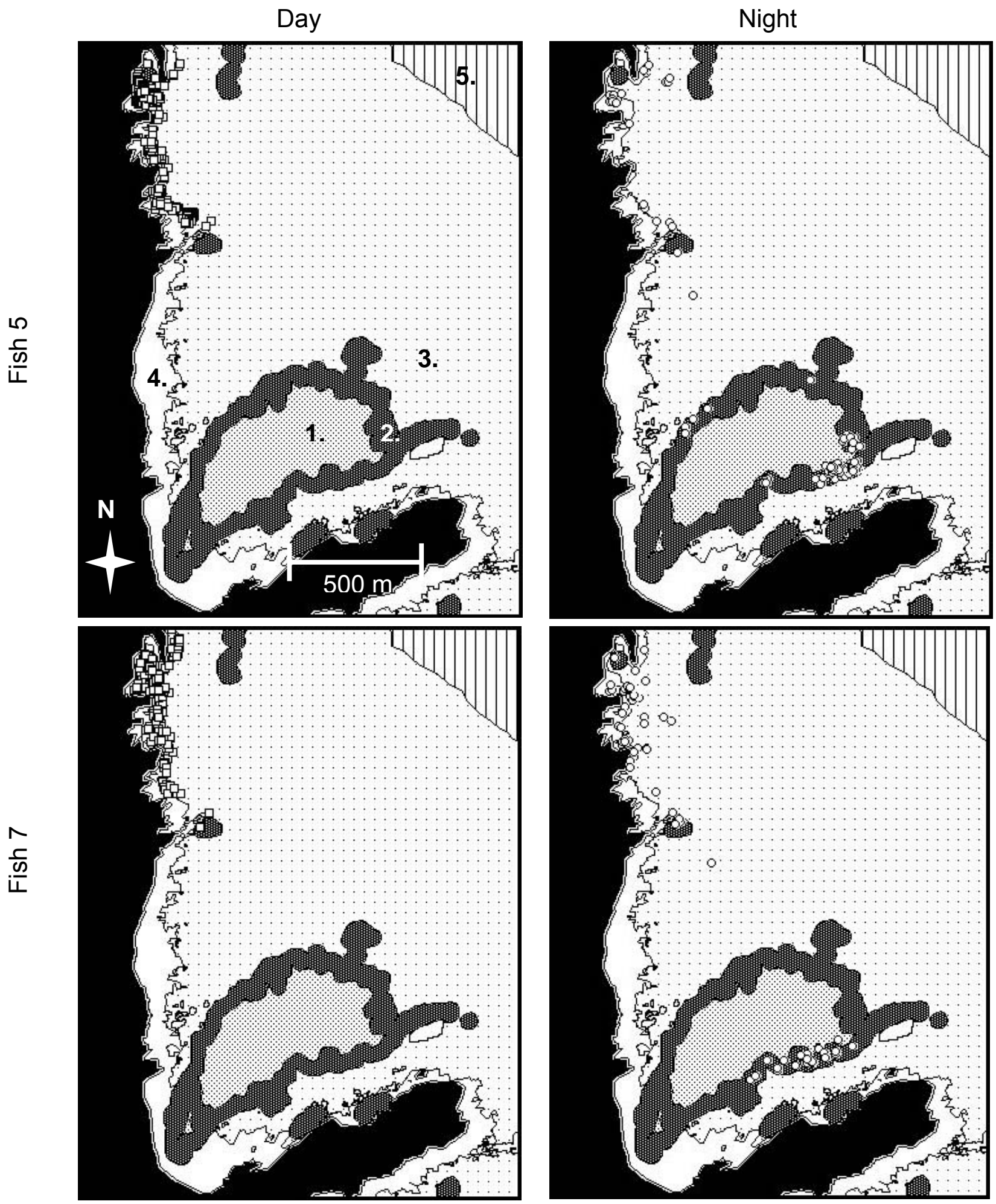
Table 3. Measures of Sarpa salpa movement in the Calvi Bay \& in the Lavezzi.

\begin{tabular}{rrrcrrr}
\hline $\begin{array}{c}\text { Fish } \\
\mathrm{n}^{\circ}\end{array}$ & $\begin{array}{c}\text { Overall track } \\
\text { distance }(\mathrm{m})\end{array}$ & $\begin{array}{c}\text { Maximum } \\
\text { speed } \\
(\mathrm{m} / \text { day })\end{array}$ & $\begin{array}{c}\text { Core area } \\
\left(\mathrm{m}^{2}\right)\end{array}$ & KHR 95\% & \multicolumn{1}{c}{$\begin{array}{c}\mathrm{r}^{2} \\
\left(\mathrm{~m}^{2}\right)\end{array}$} & Eccentricity \\
\hline & & & & & & \\
1 & 1093.9 & 9.3 & 255 & 1596 & 10359 & 3.12 \\
2 & 4752.5 & 584.1 & 5723 & 22067 & 11258 & 1.37 \\
3 & 10598.2 & 633.7 & 5563 & 19655 & 28249 & 2.14 \\
4 & 5132.4 & 225.7 & 2519 & 7612 & 6598 & 2.58 \\
5 & 19354.2 & 640.4 & 3964 & 31817 & 40206 & 2.53 \\
6 & 7802.2 & 455.6 & 1328 & 7116 & 5104 & 1.36 \\
7 & 22014.1 & 440.6 & 3645 & 24800 & 25012 & 2.29 \\
8 & 55260.8 & 995.2 & 25222 & 278711 & 285305 & 3.15 \\
9 & 7076.7 & 338.9 & 524 & 2430 & 6953 & 1.45 \\
10 & 5615.5 & 292.3 & 2685 & 17659 & 16841 & 1.63 \\
11 & 32456.2 & 462.7 & 11654 & 104290 & 61639 & 1.75 \\
12 & 10389.8 & 10.4 & 11768 & 101177 & 7841 & 1.88 \\
13 & 7470.9 & 104.9 & 9768 & 71829 & 54632 & 1.99 \\
17 & 7423.9 & 84.3 & 265 & 1991 & 1163 & 1.08 \\
\hline
\end{tabular}

\section{Home range}

Although individuals exhibited considerable variation in the size of their home range on successive days, the general areas occupied remained fairly consistent throughout the tracking period. Excepted for the fish 8, with unusual large core area, high maximum speed and dispersion factor (respectively, $25222 \mathrm{~m}^{2}$; 995m/day; $285305 \mathrm{~m}^{2}$ ), $\mathrm{r}^{2}$, the dispersion's factor varied from $5104 \mathrm{~m}^{2}$ to $61639 \mathrm{~m}^{2}$ and the eccentricity varied from 1.36 to 3.12 (table 3).

The night sites, for the three measures of home range examined $(95,75$ and $50 \%)$, were significantly larger than the day sites (Paired $t$ test, $\mathrm{df}=12, \mathrm{P}<0.01$ ). The night and day areas for all subjects during the entire tracking periods were plotted on all substratum (Figure 5). The night and day sites of fish 7,8 and 13 are illustrative of the two different locations for the day and night sites (Figure 6). The activity core is characterised by a small single spot for the day and two spots during the night (Figure 6). All fish but the fish 1 and 4 displayed those types of space use patterns. Fish 1 was followed only during 2 nights and then it was lost, the results of the night activity core analysis was a single spot. Fish 4 stayed in the vicinity of the STARESO harbour even during the nights.

Tracked fish concentrated their daytime activity in core areas rather than utilising all parts of their home range with equal intensity. Mean core areas for all the fish but the fish 8 were between 255 and $11768 \mathrm{~m}^{2}$ and usually encompassed $18.5 \pm 7.2 \%$ of the home range area. Fish 8 had an unusual large home range of 278714,44868 and $25222 \mathrm{~m}^{2}(95,75$ and $50 \%$ contour level) nevertheless, the core area used by this fish was restricted likewise the other tagged fish and encompassed $9.05 \%$ of the daily home range. 
Fig. 5. Temporal changes in the size of the home range areas of Sarpa salpa in the Calvi Bay. The mean sizes of 95,75 and $50 \%$ contour levels are shown for day and night observations (+/$\mathrm{SD})$.

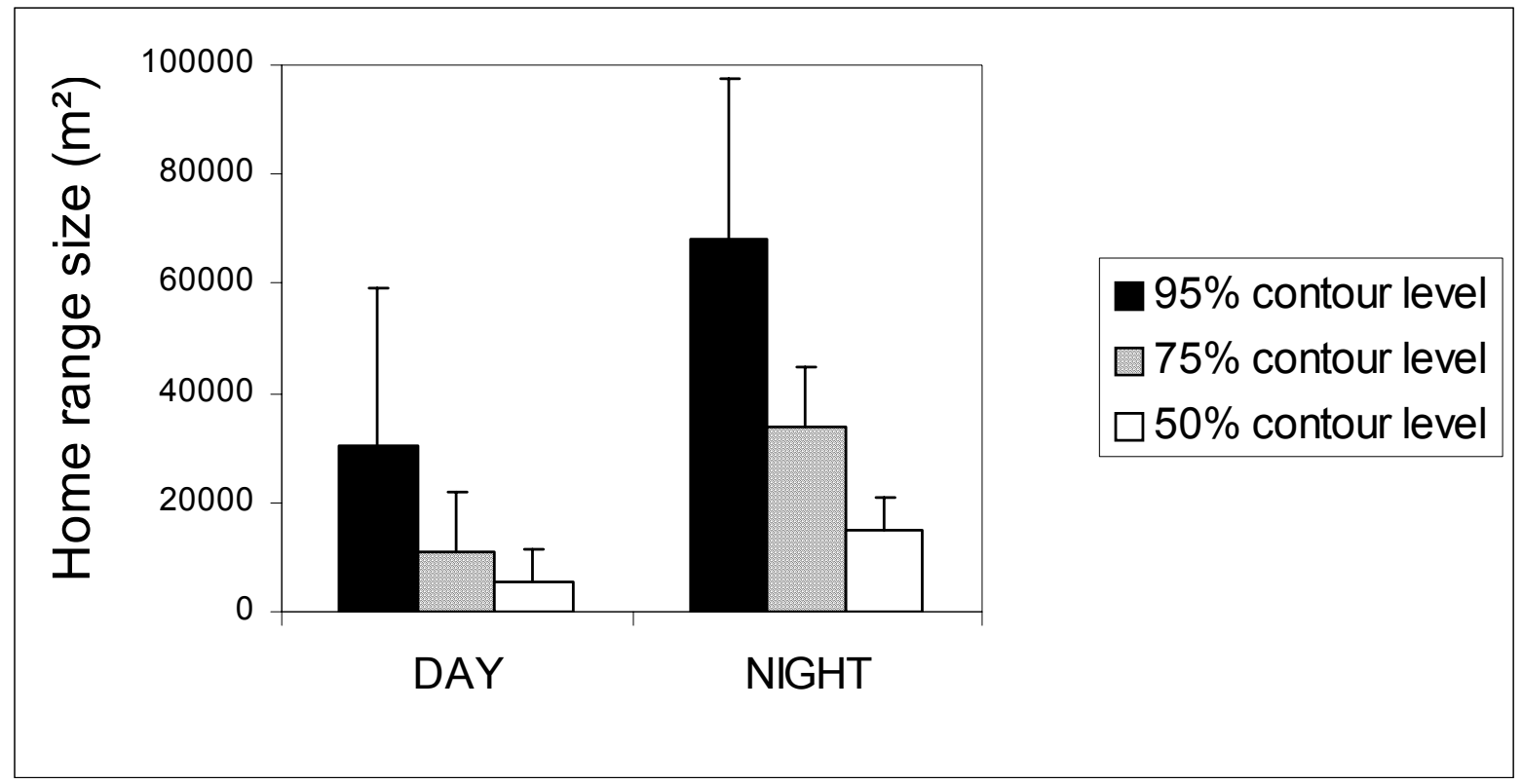


Fig. 6. Day- and night activity core (for 95,75 and $50 \%$ contour level) for the salema 7,8 and 13 in the Calvi bay. Each square represent a day positional fix and each round a night fix.
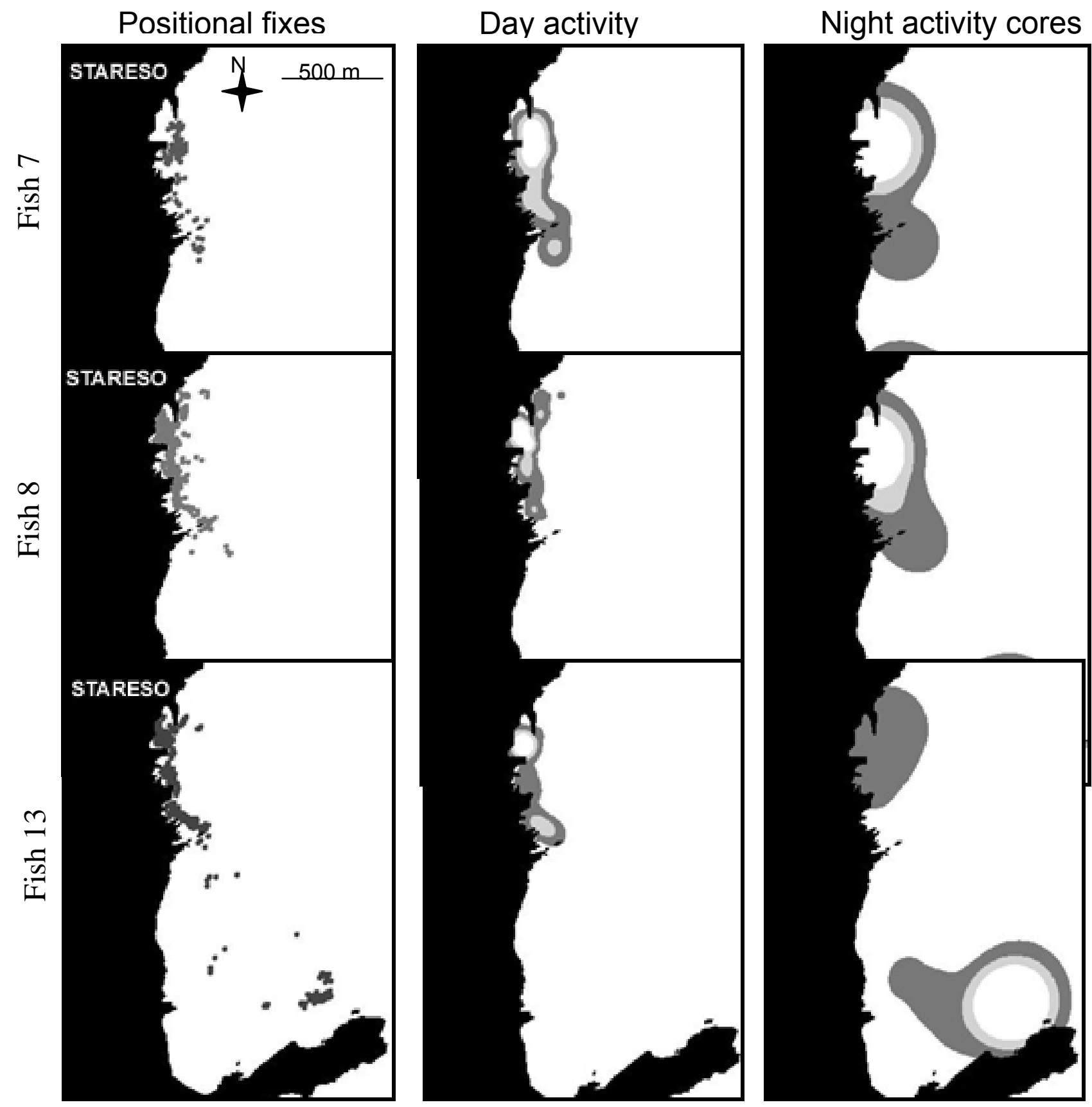


\section{Habitat utilisation}

The fish tracked in the Bay of Calvi were substratum-specific, utilising Posidonia meadow and epilithic algae during the day (represented by 51 and $41 \%$ of the fixes respectively) (Figure 7). During the night the fish were resting either in an area similar as the day activity core, or in a particular area, situated at the limit of the posidonia meadow and a sandy patch. The location of the fish 5 and 7 during the day and the night on the different substratum is shown on Figure 4. During the night time $28 \%$ of the fixes were located on the limit zone and respectively 41 and $31 \%$ on the posidonia or the algae. Statistical analyses indicated that there were no significant differences in the use of the substratum posidonia or algae during the $24 \mathrm{~h}$ cycle (Table 4). Furthermore, there was no significant difference in the use of the limit zone, the posidonia or algae during the night. The sand with a percentage of utilisation close to 0 was significantly less use than the 3 others.

Table 4. Comparison of space occupation during the four periods of the $24 \mathrm{~h}$ cycle (dawn, day, dusk and night). Occupation data for the different periods were tested against each other by Wilcoxon's test at 0.05 level of significance. $P$. is the substratum posidonia, $A$. is the substratum algae, $\mathrm{L}$. is the limit zone between the algae and the posidonia substratum and $\mathrm{S}$. is the substratum sand. NS is non significant, * is $p<0.01$ and ${ }^{* *}$ is $p<0.001$.

\begin{tabular}{cllllll}
\hline $\begin{array}{l}\text { Period } \\
\text { of the day }\end{array}$ & P. vs S. & P. vs A. & P. vs L. & A. vs S. & A. vs L. & S. vs L. \\
\hline Dawn & $*$ & NS & $*$ & $*$ & $*$ & $*$ \\
Day & $* *$ & NS & $* *$ & $* *$ & $*$ & $* *$ \\
Dusk & $* *$ & NS & $*$ & $* *$ & NS & $*$ \\
Night & $* *$ & NS & NS & $*$ & NS & $*$ \\
\hline
\end{tabular}

Fig. 7. Substratum used by the tagged Sarpa salpa at the Calvi site as a function of the 4 periods of time studied over the $24 \mathrm{~h}$ cycle. Limit zone was a transition zone between sand and Posidonia meadow. The dawn and dusk period were determined as respectively one hour before sunrise or sunset.

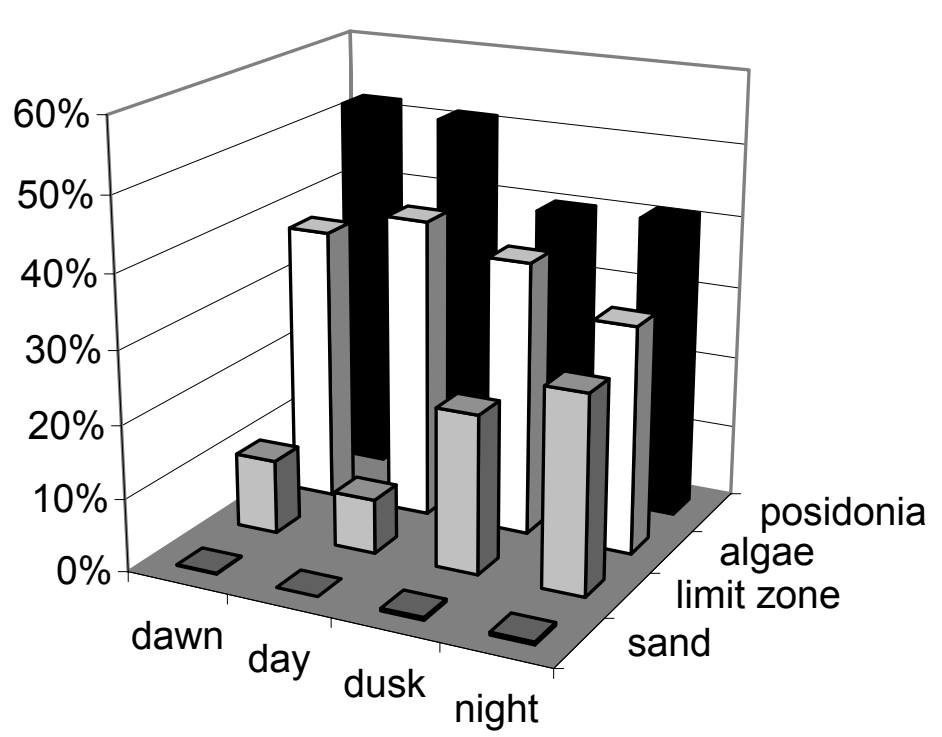


A total of 5 Sarpa salpa were caught, tagged and released in the West bay of the Lavezzi Islands (Table 1). The high loss rate of the fish tagged on October the $16^{\text {th }} 2002$ (fish 14, 15,16 and 18) were due most probably to the bad weather conditions encountered, forcing the fish to move away from the array surveyed by the buoys. Manual tracking could not allow finding them back.

None of the fish was found by the buoys array at the capture site within two days. However the capture site had become very exposed to the dominant currents during the tracking period (Fig. 1). After location of the fish 17 in the Achiarina Bay by manual tracking, the buoys array was displaced there. Fish 17 was tracked during 4 consecutive days (figure 8). The signal was found at dusk, during the night and disappeared from the acoustic buoys array at dawn. Indeed the buoys array was located on the night area of the fish and was able to estimate the night activity core. The nocturnal home range for the tracked fish was very restricted and were 1991, 854 and $266 \mathrm{~m}^{2}$ for the 95,75 and $50 \%$ contour level respectively. The substratum of the visited area by fish 17 during twilight and night periods was a limit zone between the $P$. oceanica meadow and a sandy area, or a sandy area (Figure 2B). The activity pattern of fish 17 was similar to the 13 other salemas tracked in the Calvi Bay. Distance between two positional fixes were very small (average $7 \pm 9.1 \mathrm{~m}$ ) and the swimming speed almost zero, confirming the resting activity of the fish.

Fig. 8. Positional fixes of the tagged fish in the Achiarina Bay.

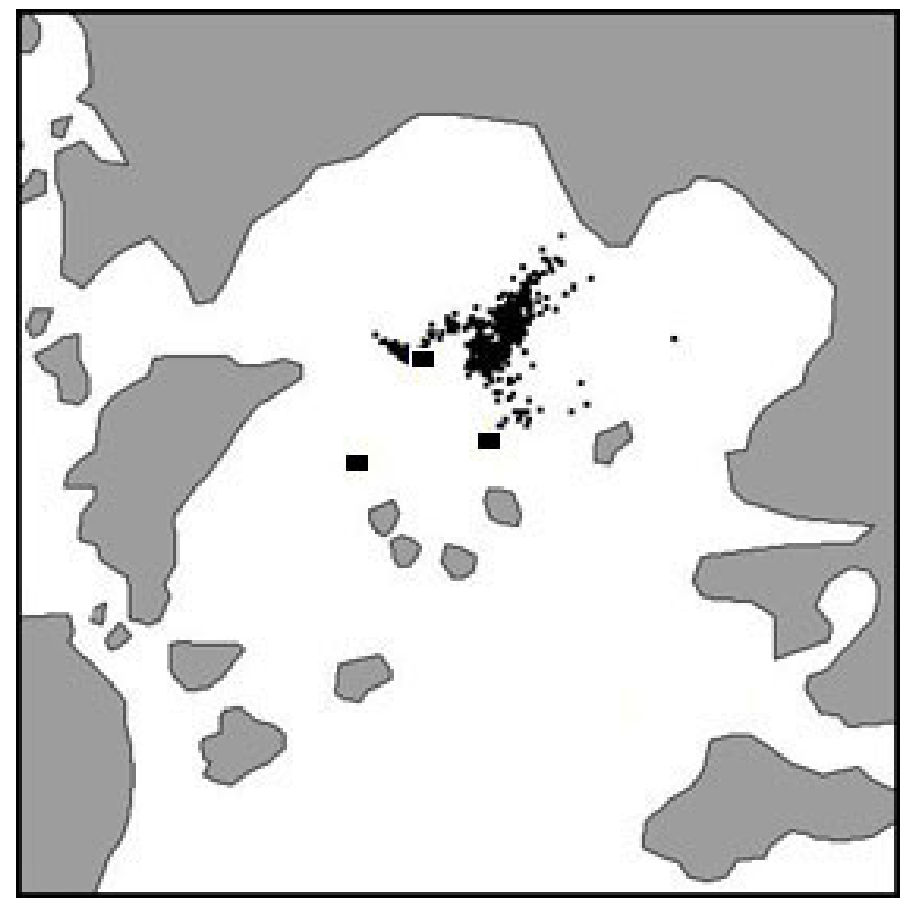

\section{Discussion}

By combining manual tracking, automated monitoring and direct diving observations, we were able to gather qualitative and quantitative information on the home range, the habitat utilisation and the movement patterns of S. salpa.

\section{Home range and movement patterns}

The home range of Sarpa salpa varied significantly between day and night. Day direct observations indicated extended periods of grazing on two main types of substrata: the Posidonia meadow or the epilithic algae. Night home range activity areas were characterised by two core areas. The first one situated at the very same site than the day activity area. The second one was situated on a very specific zone: the limit between the Posidonia meadow and 
sandy area. This particular zone is often a unique patch where a lot of fish were observed gathering. Other fish species exhibit a similar strategy, undergoing diel migration between feeding grounds and sheltered areas (Hobson, 1972; Gladfelter, 1979; Lowry and Suthers, 1998). Furthermore, in many diurnal fishes, the onset and cessation of daily activity coincides closely with the rising and the setting of the sun (Hobson, 1972; Clark and Green, 1990).

This species displayed increased activity during the day (while feeding), yet the night time (resting period) has a larger home range. This particular type of behaviour can be linked to an optimal feeding strategy, i.e. high familiarity of fixed sites to increase feeding efficiency. While resting sites were not as site specific. No correlation with weather condition, tides or external influences (predators) was found to explain the change of the two types of resting areas. Furthermore, fish tracked simultaneously were located in a resting site or another one, independently.

Interestingly, direct observations in SCUBA shown that the path used by the fish from one activity area to another, was always the same. This particular pattern of behaviour is also evident in terrestrial species, where animals make trips between non-contiguous home range areas using corridors (Jaremovic and Croft, 1987). Night resting site fidelity, which involves fish returning to the same resting location on successive nights, is also well known and has been demonstrated in several fish species (Ehrlich et al. 1977; Hobson, 1972; Clark and Green, 1990). The size of the night home range of the individual tracked in the Lavezzi shown an approximate tenfold decrease, showing ability of this species to adjust its behaviour when the environmental conditions are forcing. Nevertheless, those findings are supported only by the observation of one fish and further investigations are needed.

Ogden and Lobel (1978) defined three foraging strategies for a diurnal herbivorous fish: (1) territorial defence, (2) group foraging, or (3) individual home ranges. S. salpa is a group grazing fish within a well defined home range. The strategy adopted is related to habitat type as much as to taxonomic status (Ogden and Lobel, 1978). Home range behaviour develops where the food is neither limiting nor widely used by other species (Horn, 1989). Indeed, the Corsican Posidonia meadows is among the more productive ecosystems of the Mediterranean Sea (Boudouresque et al., 1984), and S. salpa is the only fish grazer of this seaweed (Cebrian et al., 1996), the competition for the resource is then very limited and favours a home range foraging strategy.

Individuals showed a clear preference for a very limited number of locations within the home range; this particular behaviour has been reported for many species of fish (Bradbury et al., 1995; Eristhee and Oxenford, 2001). Evolutionary advantages of this particular behaviour, which implies the use within the home range of a restricted number of preferred sites and therefore induce an extreme familiarity with localised areas, have been put forward to improve feeding efficiency and to reduce risk of predation (although predation for S. salpa is not well documented in the Calvi Bay).

\section{Substratum utilization}

Our study showed that $S$. salpa was a substratum specific species in the Mediterranean. During the day the salema was found either on the Posidonia meadow or on the epilithic algae. And during the night fish sheltered on the same site as day-time or on a limit zone between the meadow and sandy patches. Cebrian (1996) showed that S. salpa select productive meadows, and Verlaque (1990) that the salema adapted the grazing activity with the abundance of the plant/algae, showing its ability to adapt its behaviour to the environment. Therefore, caution must be applied in extrapolating ecological data from a single zone to a large area. Hence, studies on different meadows, throughout the year have to be done to avoid a false estimation of the herbivore ecological role in such ecosystem.

\section{Homing}

Homing is an animal ability to return to territory or original capture site after displacement (Wootton, 1990). Our displacement experience demonstrated that the salema could return to the point of capture, with $100 \%$ of the displaced fish returning to the capture site within two days. The stimuli used to determine direction may include vision through the recognition of landmarks, olfactory stimulation, the use of a sun compass, the pattern of polarized light in the sky and water currents (Hasler and Wisby, 1958, Wootton, 1990).

In the Lavezzi site, the fish did not return to the capture site. This can be explained by the violent winds blowing (and therefore currents and swell) in this area at the time of the tracking session. The fish probably moved to a more protected area, less exposed to the wind, like the 
Achiarina bay (where fish 17 was found together with occasional signals from the other fish) which was a semi-closed bay with the opening not directed to the dominant winds, currents or swell.

If the homing behaviour is well documented in several marine tropical and temperate fish species (Crossman, 1977; Lowry and Suthers, 1998; Lembo et al., 1999) it is the first time that this particular behaviour is demonstrated for S. salpa. Once established in areas of suitable substrata, fish could maintain their occupancy through the ability to return to the same location over time. Homing ability also sustains populations in one area, acting to stabilise spatial distribution; although functionally different, it has similar purpose to territoriality exhibited in other species (Green, 1971; Crossman, 1977).

Our study showed that the incorporation of fish position data sets into GIS greatly enhanced their usefulness in examining spatial and temporal patterns of movement in relation to substratum (Eristhee and Oxenford, 2001). Nevertheless, further studies should be done to investigate the behaviour of this fish during the winter months, as Sarpa salpa are present in the Calvi bay during the summer months, and afterwards move away to a deeper unknown sites at the end of the fall. Further, as the bathymetric repartition and the foraging behaviour of the salema is size dependant (Verlaque, 1990), further studies should be done to investigate the habitat utilisation and feeding habit of larger individuals. The better knowledge of movement patterns, habitat utilisation, and home range of salemas are of great interest for the eventual protection of their population.

\section{Acknowledgements}

We thanks E. Guyot and D. Collard from the CEGEL, for assistance in the field in the Lavezzi Islands. Support for this paper was provided by a PhD research grant from FRIA (Fonds pour la Formation à la recherche dans l'Industrie et l'Agriculture) to the first author. The authors wish to thanks the staff of the STARESO marine research station and the staff of the Réserve Naturelle des Bouches de Bonifacio. This article is a MARE publication (MARE xx).

\section{Bibliography}

Bauchot M.-L. \& J.-C. Hureau, 1990. Sparidae, pp. 790-812. In: Quéro J.-C., Hureau J.-C., Karrer C., Post A., Saldanha L. (Ed.). Checklist of the Fishes of the eastern tropical Atlantic Catalogue des poissons de I'Atlantique tropical oriental (Clofeta). Paris, Unesco, 1990, 3 vol., $x x x i+1492 \mathrm{p}$.

Bégout Anras, M.L., Cooley, P.M., Bodaly, R.A., Anras, L., Fudge R.J.P. 1999. Movement and habitat use by lake whitefish during spawning in a boreal lake: integrating acoustic telemetry and geographic information system. Transactions of the American Fisheries Society, 128: 939-952.

Boudouresque, C.F., Jeudy de Grissac, A., Olivier, J. 1984. International Workshop on posidonia beds. G.I.S. Posidonie publication, $454 \mathrm{pp}$.

Bouquegneau, J.M., Dauby, P., Soullard, M., Gobert, S, Lepoint, G., J.P. Nellissen, Havelange, S. 1994. Elements stocks and fluxes in the Posidonia oceanica ecosytem of the Mediterranean. In: M. Jangoux (ed.). STEP research programme. Final report. Contrat step0063-C, Brussels: 47-56.

Bradbury C., Green, . J.M., Bruce-Lockhart, M. 1995. Home ranges of female cunner, Tautogolabrus adspersus (Labridae), as determined by ultrasonic telemetry. Canadian Journal of Zoology, 73: 1268-1279.

Cebrian, J., Duarte, C.M., Marba, N., Enriquez, S., Gallegos, M., Olesen,, B. 1996. Herbivory on Posidonia oceanica: magnitude and variability in the Spanish Mediterranean. Marine Ecology Progress Series, 30: 147-155.

Cebrian, J., Duarte, C.M., Marba, N., Enriquez, S., 1997. Magnigtue and fate of the production of four co-occuring Western Mediterranean seagrass species. Mar. Ecol. Prog. Ser., 155, 29-44.

Cebrian, J. and C. M. Duarte. 2001. Detrital stocks and dynamics of the seagrass Posidonia oceanica (L.) Delile in the Spanish Mediterranean. Aquat. Bot. 70: 295-309.

Chevaldonne, P. 1990. Ciguatera and the saupe, Sarpa salpa (L.), in the Mediterranean: a possible misinterpretation. Journal of Fish Biology, 37: 503-504. 
Clark, D.J., and Green, J.M. 1990. Activity and movement patterns of juvenile Atlantic cod, Gadus morhua, in Conception Bay, Newfoundland, as determined by sonic telemetry. Canadian Journal of Zoology, 68: 1434-1442.

Crossman, E. 1977. Displacement and home range movements of muskellunge determined by ultrasonic tracking. Environmental Biology of Fishes, 1: 145 - 158.

De Vaugelas, J., Meinesz, A., Bonnin, A., Chiaverini, D. and Cottalorda, J.M. 1995. Etude de faisabilité du Parc marin international des bouches de Bonifacio. Cartographie des fonds marins, des criques les plus fréquentées par la plaisance (Corse du sud). Ed. LEML-UNSA, 41 pp. 13 cartes.

Ehrlich, P.R., Talbot, F.., Russel, B.C., and Anderson, G.R.V. 1977. The behaviour of chaetodontid fishes with special reference to Lorenz's "poster colouration" hypothesis. Journal Oof Zoology, 183: 213-228.

Eristhee, N., and Oxenford H.A. 2001. Home range size and use of space by Bermuda chub Kyphosus sectatrix (L.) in two marine reserves in the Soufrière Marine management Area, St Lucia, West Indies. Journal of Fish Biology, 59 (A): 129-151.

Ferguson, R.L., Thayer, G.W., Rice, T.R., 1980. Marine primary producers. Functional adaptations of marine organism. Academic press, $69 \mathrm{pp}$.

Francour, P. 1997. Fish assemblages of Posidonia oceanica beds at Port-Cros (France, NW Mediterranean): Assessment of composition and long-term fluctuations by visual census. Marine Ecology, 18 (2) : 157-173.

Francour, P. 2000. Evolution spatio-temporelle à long terme des peuplements de poissons des herbiers à Posidonia oceanica de la réserve naturelle de Scandola (Corse, Méditerranée, Nord-occidentale). Cybium, 24 (3): 85-95.

Gladfelter, W.B. 1979. Twilight migrations and foraging activities of the copper sweeper Pempheris schomburgki (Teleostei: Pempheridae). Marine Biology, 50: 109-119.

Green, J.M. 1971. High tide movements and homing behaviour of the tidepool sculpin Oligocottus maculosus. Journal of Fisheries Research Board of the Canada, 28: 383 - 389.

Hasler, A.D., and Wisby, W.J. 1958. The return of displaced large mouth bass and green sunfish to a "home area". Ecology, 39: 289-293.

Havelange, S., Lepoint, G., Dauby, P., Bouquegneau, J.M. 1997. Feeding of the sparid fish Sarpa salpa in a seagrass ecosystem: diet and carbon flux. Marine Ecology, 18: 287-297.

Hemminga, M.A., Harrison, P.G., van Lent, F., 1991. The balance of nutrient losses and gains in seagrass meadows. Mar. Ecol. Progr. Ser. 71, 85-96.

Hobson, E.S. 1972. Activity of Hawaiian reef fishes during the evening and the morning transition between daylight and darkness. Fisheries Bulletin US 70: $715-740$.

Holland, K.N., Lowe, C.G., Peterson, J.D., Gill, A. 1992. Tracking coastal sharks with small boats: Hammerhead shark pups as a case of study. Australian Journal of Marine and Freshwater Resources, 43: 61-66.

Hooge, P.N., Eichenlaub, B., Solomon, E.K. 1997. Animal movement extension to Arcview. Ver. 1.1. Alaska Biological Science centre, U.S., Geological Survey, Anchorage, AK, USA.

Horn, M.H. 1989. Biology of marine herbivorous fishes. Oceanography and Marine Biology Annual Review, 27: $167-272$.

Jadot, C., Graux, D., Michel, C., Voss, J. 2000. Contribution à la caractérisation du comportement reproducteur et alimentaire de la Saupe (Sarpa salpa (Linné, 1758)). Cahier d'Etholologie, 20: 33-44.

Jadot C., M. Ovidio \& J. Voss. 2002. "Diel activity of Sarpa salpa (Sparidae) by ultrasonic telemetry in a Posidonia oceanica meadow of Corsica (Mediterranean sea)." Aquatic Living Resources, 15: 343-350.

Jadot, C. 2003. Comparison of two tagging techniques for Sarpa salpa: external attachment and intraperitoneal implantation. Oceanologica Acta, 26: 497-501.

Jaremovic, R.V., and Croft D.B. 1987. Comparison of techniques to determine Eastern grey kangaroo home range. Journal of Wildlife Management, 51: 921-930.

Klimley, A.P., le Bœuf B.J., Cantara, K.M., Richert, J.E., Davis, S.F., Van Sommeran, S. 2001. Radio-acoustic positioning as a tool for studying site specific behavior of the white shark and other large marine species. Marine Biology 138: 429-446.

Klumpp, D.W., Howard, R.K., and Pollard, D.A., 1989. Trophodynamics and nutritional ecology of seagrass communities. In: larkum, A.W.D., McComb, A.J., Shepherd, S.A. (Eds.), Biology of seagrasses: A treatise on the biology of seagrasses with special reference to the Australian region. Elsevier, Amsterdam, pp 394-457.

Lembo, C., Fleming, I.A., Økland, F., Carbonara, P., Spedicato, M.T., 1999. Site fidelity of the dusky grouper Epinephelus marginatus (Lowe, 1834) studied by acoustic telemetry. Marine Life 9 (2): $37-43$. 
Lissia-Frau, A.M. 1966. Ricerche sul differenziamento sessuale di Boops salpa (L.) (Teleostei, Perciformes). Atti Academia Gioenia, 6 ser. 18: 165-174.

Lissia-Frau, A.M. 1968. Le manifestazioni della sessualita negli Sparridii (Teleostei, Perciformes). Studi Sassar, 1: 1-23.

Lowry, M.B., and Suthers, I.M. 1998. Home range, activity and distribution patterns of a temperate rocky-reef fish, Cheiladactylus fuscus. Marine Biology 132: 569- 578.

Mendez - Villamil, M., Pajuelo, J.G., Lorenzo, J.M., Coca J., Ramos, A.G. 2001. Age and growth of the salema, Sarpa salpa (Osteichtyes, Sparidae), off the Canary Islands (East-Central Atlantic). Archive of Fishery and Marine Research, 49 (2): 139-148.

Méndez - Villamil, M., Lorenzo J.M., Pajuelo, J.G., Ramos, A., Coca, J. 2002. Aspects of the live history of the salema, Sarpa salpa (Pisces, Sparidae), of the Canarian Archipelago (central-east Atlantic). Environmental Biology of Fishes, 63: 183-192.

O'Dor, R.K., Andrade, Y., Webber, D.M., Sauer, W.H.H., Roberts, M.J., Smale, M.J., Voegeli, F.M. 1998. Applications and performances of radio acoustic positioning and telemetry (RAPT) systems. Hydrobiologia, 371/372: 1 - 8.

Ojeda, F.P., Munoz, A.A., 1999. Feeding selectivity of the herbivorous fish Scartichtys viridis : effects on macroalgal community structure in a temperate rocky intertidal coastal zone. Mar. Ecol. Prog. Ser. $184: 219,229$.

Pergent, G., Romero, J., Pergent-Martini C., Mateo, M., Boudouresque, C., 1994. Primary production, stocks and fluxes in the Mediterranean seagrass Posidonia oceanica. Mar. Ecol. Progr. Ser.106: 139-146.

Pergent G., Rico-Raimondino, V., Pergent-Martini, C., 1997. Fate of primary production in Posidonia oceanica meadows of the Mediterranean. Aqut. Bot. 59, 307 - 321.

Ruitton, S., Francour, P., C.F. Boudouresque. 2000. Relation between Algae, Benthic Herbivorous invertebrates annd fishes in rocky sublittoral communities of a temperate sea (Mediterranean). Estuar. Coast. Shelf Sci. 50: 217-230.

Sargian, P. 1997. Contribution à la cartographie de la bande rocheuse infralittorale et de I'herbier à Posidonia oceanica dans la baie de la Revellata (Calvi). Msc thesis. University of Corsica. France.

Sellami, A. and Bruslé, J. 1975. Contribution à l'étude de la sexulatié de la saupe Boops salpa Linnaeus 1758 (Téléostéen Sparidae) des côtes de Tunisie. Vie Milieu, 23 (2)A : 261-276.

Spanier, E. 1988. Ciguatera-like poisoning in the Mediterranean. Veterinary and Human Toxicology, 30 (6): 352-353.

Spanier, E., Finkelstein, Y. and Raikhlin - Eisenkraft B. 1989. Toxicity of the saupe, Sarpa salpa (Linnaeus, 1758), on the Mediterranean coast of Israel. Journal of Fish Biology, 34: 635636.

Velimirov, B. 1984. Grazing of Sarpa salpa L. on Posidonia oceanica and utilization of soluble compounds. In: Boudouresque C.F., Jeudy de Grissac, A., Olivier, J. (Eds), International Workshop on Posidonia oceanica Beds GIS Posidonie publ. France, 1: 381-387.

Verlaque, M. 1990. Relations entre Sarpa salpa (Linnaeus, 1758) (Téléostéen, Sparide), les autres poissons brouteurs et le phytobentos algal méditerranéen. Oceanologica Acta 13 (3): 373-388.

Winter, J. 1996. Advances in underwater biotelemetry. In Fisheries techniques. Ed by B.R. Murphy and D.W. Willis. 2nd ed. American Fisheries Society, Bethesda, Maryland, 555 - 590.

Wotton, R.J. 1990. Ecology of teleost fishes. Chapman and Hall, London, 404pp.

Zamora, L., and Moreno-Amich, R. 2002. Quantifying the activity and movement of perch in a temperate lake by integrating acoustic telemetry and a geographic information system. Hydrobiologia, 483: 209-218. 